\title{
The Effect of Chrysin on Oxidative Stress in the Ovarian Tissue of Aspirin Administered Rats
}

\author{
Ahmet Ufuk Komuroglu (Corresponding author) \\ Vocational School of Health Services, \\ Van Yuzuncu Yil University 65080, Van, Turkey \\ E-mail: aukomuroglu@yyu.edu.tr \\ Deniz Dirik \\ Department of Obstetric and Gynecology, Faculty of Medicine, \\ Van Yuzuncu Yil University, 65080, Van, Turkey \\ E-mail: denizdirik@yyu.edu.tr
}

\begin{abstract}
Aspirin is a medication with anti-inflammatory and antioxidant properties. Chrysin is a natural flavonoid that has been extensively investigated for its significant biological impacts. In this study, we aimed to investigate the protective effect of chrysin against aspirin-induced oxidative damage in rat ovarian tissue.

Forty female albino rats were used in the study. Rats were randomly divided into 5 groups. Group 1 (control group): No medication was administered to the rats in this group. Group 2 (ASA group): 1 $\mathrm{mg} / \mathrm{kg}$ aspirin was administered to rats in this group by oral gavage for 28 days. Group 3 (ASA+CH): 1 $\mathrm{mg} / \mathrm{kg}$ aspirin and $50 \mathrm{mg} / \mathrm{kg} \mathrm{CH}$ were administered to rats in this group by oral gavage for 28 days. Group $4(\mathrm{CH}): 50 \mathrm{mg} / \mathrm{kg} \mathrm{CH}$ was administered by oral gavage to the rats in this group for 28 days. Group 5 (olive oil): $1 \mathrm{ml} / \mathrm{kg}$ of olive oil was administered orally to the rats in this group. At the end of the 28-day trial, ovarian tissues were taken under anesthesia, after the rats fasted for one night. The supernatant was obtained by homogenizing the ovarian tissues, and Malondialdehyde (MDA), Advanced Oxidation Protein Products (AOPP), Total sulfhydryl (T-SH) level, and catalase (CAT) activity were quantified spectrometrically from the supernatant.

Ovarian tissue MDA and AOPP levels in the ASA group were determined to be significantly higher than in the control group $(\mathrm{p}<0.05)$. Ovarian tissue MDA level in the ASA $+\mathrm{CH}$ group was lower compared to the ASA group, but the difference between the two groups was not significant $(p>0.05)$. The AOPP level of the ASA $+\mathrm{CH}$ group was found to be significantly lower than that of the ASA group $(p<0.05)$. T-SH level of the ASA group was significantly lower than the control group ( $<<0.05)$. No significant difference was determined between T-SH levels of the ASA and AS+CH group ( $>0.05$ ). CAT activity in the ASA group was lower than in the control group, but the decrease was not significant $(\mathrm{p}>0.05)$. Ovarian tissue CAT activity was found to be significantly higher in the ASA $+\mathrm{CH}$ group, compared to the control and ASA groups $(\mathrm{p}<0.05)$.

ASA administration causes an increase in oxidative stress markers from the ovarian tissue, whereas it causes a decrease in antioxidants. By reducing this effect of aspirin, $\mathrm{CH}$ could increase antioxidant levels and reduce oxidative stress
\end{abstract}

Keywords: Aspirin, Chrysin, Ovarian tissue, oxidative stress, antioxidant

\section{Special Issue of Health Sciences}

DOI: $10.7176 / \mathrm{JSTR} / 7-08-05$

\section{Introduction}

Acetylsalicylic acid (ASA), also known as aspirin, is widely used as an antiplatelet agent and is the mainstay of pharmacological therapy in the prevention of atherothrombotic complications associated with cardiovascular disease (182). Inhibits ASA cyclooxygenase-1 (COX-1) enzyme and so that blocks platelet thromboxane A2 (TXA2) synthesis (187). Aspirin can act as an antioxidant in neutralizing hydrogen peroxide with the same impact on TXA2 production via COX-1. The role of aspirin in

38 I P a g e

www.iiste.org 
primary prevention is controversial, albeit its benefits in secondary prevention are well established [1]. The World Health Organization promotes the inclusion of herbal medicines in national health care programs. Reactive species are generated through the metabolism of medications. Although aspirin is an analgesic medication, it may induce oxidative stress. Plants or herbal products with antioxidant properties could be benefitted to reduce the oxidative damage of these reactive species [2]. Polyphenols are natural micronutrients that are secondary plant metabolites responsible for various functional characteristics of plants [3]. Flavonoids are a broad class of polyphenolic secondary metabolites abundant in plants [4]. Chrysin is a phytochemical that is characterized under the class of flavonoids. Propolis is found abundantly in honey, passion fruit, and even mushrooms, and other plant sources [5]. Chrysin, a common natural flavonoid, has been reported to have various biological activities such as antioxidant, anti-virus, anti-anxiolytic [4]. Chrysin $(\mathrm{CH})$ decreases the inflammatory response in macrophages and monocytes by reducing pro-inflammatory cytokines [6]. $\mathrm{CH}$ has been shown to protect the oxidative stress of the ovaries by reducing oxidative stress and increasing the level of antioxidant enzymes [7].

Our objective in the present study is to find out the impact of aspirin on the antioxidant oxidant system in ovarian tissue and to assess the potential protective and therapeutic effect of $\mathrm{CH}$. In order to reveal these effects, we investigated malondialdehyde, AOPP, total sulfhydryl group level, and catalase activity in rat ovarian tissue.

\section{Material and Metod}

\subsection{Chemicals}

Chrysin (97\%) was purchased from Sigma-Aldrich (C80105). CH was prepared by dissolving in corn oil. Aspirin was purchased from the local pharmacy (Aspirin ${ }^{\circledR}, 100 \mathrm{mg}$ tablet, Bayer). Aspirin tablets were dissolved in distilled water.

\subsection{Animal and experimental design}

Forty female Wistar albino rats were used in the study. Rats were 8-10 weeks old and weighed 200-250 g. Rats were procured from Van Yuzuncu Yil University Experimental Animals Unit. All practices in the study were performed in compliance with the ethical principles. Before the onset of the study, ethical approval was obtained from the Experimental Animals Local Ethics Committee of Van Yuzuncu Yil University.

Forty rats were divided into 4 groups as control, aspirin (ASA), aspirin + Chrysin $(\mathrm{ASA}+\mathrm{CH})$, and $\mathrm{CH}$. Group1 (control group): No medication was administered to the rats in this group.

Group 2 (ASA group): $1 \mathrm{mg} / \mathrm{kg}$ aspirin was administered to rats in this group by oral gavage for 28 days.

Group $3(\mathrm{ASA}+\mathrm{CH}): 1 \mathrm{mg} / \mathrm{kg}$ aspirin and $50 \mathrm{mg} / \mathrm{kg} \mathrm{CH}[8]$ were administered to rats in this group by oral gavage for 28 days.

Group $4(\mathrm{CH}): 50 \mathrm{mg} / \mathrm{kg} \mathrm{CH}(192)$ was administered by oral gavage to the rats in this group for 28 days.

Group 5 (corn oil): $1 \mathrm{ml} / \mathrm{kg}$ of corn oil was administered orally to rats in this group.

\subsection{Collection of samples}

The rats were anesthetized 24 hours after the last administration. Ovarian tissues were collected for biochemical analysis. Subsequently, the ovarian tissue was homogenized in phosphate buffer. The supernatant obtained was used for biochemical analysis.

\subsection{Biochemical analysis}

AOPP level was determined using the method described by V. Witko-Sarsat [9]. AOPP concentration was expressed as $\mu \mathrm{mol} / \mathrm{g}$ tissue. Total sulfhydryl content (protein and non-protein thiols) was computed by the method of Sedlak and Lindsay [10]. The concentration of sulfhydryl groups was expressed as $\mu \mathrm{mol} / \mathrm{gr}$ tissue. Malondialdehyde levels determined using the method described by Ohkawa [11] Catalase (CAT) activity was determined using the method described by Lartillot et al. [12].

\subsection{Statistic analysis}

All statistical analyzes were performed using the software of SPSS 20.0. The results are presented as the mean \pm standard deviation $(\mathrm{M} \pm \mathrm{SD})$. All statistical comparisons were performed using oneway ANOVA followed by Duncan's multiple range post hoc analysis. The results were considered significant at $\mathrm{p}<0.05$. 


\section{Results}

Compared to the control group, the ovarian tissue MDA and AOPP levels of the aspirin-administered group (ASA group) were found to be significantly higher. The ovarian tissue MDA and AOPP levels were lower in the ASA $+\mathrm{CH}$ group compared to the ASA group; however, the difference between the two groups was not significant.

The ovarian tissue T-SH level of the control group was determined to be significantly higher than the ASA group. Although the ovarian T-SH level was higher in the ASA $+\mathrm{CH}$ group compared to the ASA group, this elevation was not significant. The ovarian tissue CAT activity was higher in the ASA group compared to the control group, but this elevation was not significant. Ovarian tissue CAT activity in the $\mathrm{ASA}+\mathrm{CH}$ group was determined to be significantly higher than in the ASA group.

Table 1. MDA, AOPP, TSG level and CAT activity in Ovarian Tissue in study groups

\begin{tabular}{|c|l|l|l|l|l|}
\hline & Control group & ASA & ASA + CH & CH & CO \\
\hline $\begin{array}{c}\text { MDA } \\
\text { (nmol/gr } \\
\text { tissue) }\end{array}$ & $0.38 \pm 0.01^{\mathrm{b}}$ & $0.420 \pm 0.02^{\mathrm{a}}$ & $0.40 \pm 0.02^{\mathrm{a}, \mathrm{b}}$ & $0.40 \pm 0.01^{\mathrm{a}, \mathrm{b}}$ & $0.39 \pm 0.01^{\mathrm{a}, \mathrm{b}}$ \\
\hline $\begin{array}{c}\text { AOPP } \\
(\mathrm{mmol} / \mathrm{gr} \\
\text { tissue }\end{array}$ & $30.54 \pm 1.13^{\mathrm{c}}$ & $34.12 \pm 0.97^{\mathrm{a}}$ & $32.37 \pm 0.64$ & $31.60 \pm 0.84^{\mathrm{b}, \mathrm{c}}$ & $31.96 \pm 1.06^{\mathrm{b}, \mathrm{c}}$ \\
\hline $\begin{array}{c}\text { TSG } \\
\text { mmol/gr } \\
\text { tissue })\end{array}$ & $0.59 \pm 0.02^{\mathrm{a}, \mathrm{b}}$ & $0.53 \pm 0.01^{\mathrm{d}}$ & $0.54 \pm 0.02^{\mathrm{b}, \mathrm{d}}$ & $0.57 \pm 0.01^{\mathrm{b}, \mathrm{c}}$ & $0.61 \pm 0.02^{\mathrm{a}}$ \\
\hline CAT (U/L) & $616.71 \pm 115.11^{\mathrm{a}, \mathrm{b}^{*}}$ & $516.80 \pm 97.84^{\mathrm{b}}$ & $728.13 \pm 98.31^{\mathrm{a}}$ & $597.78 \pm 96.30^{\mathrm{b}}$ & $723.21 \pm 53.41^{\mathrm{a}}$ \\
\hline
\end{tabular}

* Different letters on the same line represent statistical significance.

ASA: Aspirin group, $\mathrm{ASa}+\mathrm{CH}$ : Aspirin $+\mathrm{CH}$ group, $\mathrm{CH}$ : Chrysin group, $\mathrm{CO}$ : corn oil group, MDA: Malondialdehyde, AOPP: advanced oxidation protein products, TSG: total sulfhydryl groups, CAT: Catalase

\section{Discussion}

Physiological and pathological processes in the human organism generate high amounts of oxidants that lead to oxidative stress and tissue damage. The balance between oxidants and antioxidants is disrupted in favor of oxidants during diseases. Aspirin disrupts the antioxidant system, resulting in worsening of clinical manifestations and prognosis of the disease. It is unclear how aspirin disrupts the antioxidant system, yet it may disrupt the antioxidant system by lowering serum levels of trace elements that act as cofactors of antioxidant enzymes [13]. Studies on the effects of therapeutic-dose aspirin on ovarian tissues are limited, though high-dose aspirin is nephrotoxic. Tissue damage caused by free radicals is associated with the degree of antioxidant system dysfunction. Preserving the antioxidant system can prevent tissue damage. Thus, the administration of natural herbal substances with antioxidant properties could reduce tissue damage induced by oxidative stress. Hence, in this study, we investigated the protective effect of Chrysin $(\mathrm{CH})$ against oxidative stress caused by aspirin in rat ovarian tissue. Aspirin administration resulted in an increase in MDA and AOPP levels as well as a decrease in T-SH levels and CAT activities in rat ovarian tissue. Besides, $\mathrm{CH}$ treatment protected the ovarian tissue from aspirin-induced oxidative stress by leading to a decrease in MDA and AOPP levels and an increase in T-SH level and CAT activity.

$\mathrm{CH}$ is a flavonoid with particularly strong complexing properties as a result of the presence of the hydroxyl group at the 5th Carbon of its molecule. It has been verified through studies on the antioxidant potential of various flavonoids that the number and distribution of hydroxyl groups in the compound are significant. Generally, the antioxidant properties of polyphenols depend on the hydroxylation of the B ring. Morover, metahydroxyl groups at positions 5 and 7 of the A ring play a minor role in the antioxidant properties of $\mathrm{CH}$ [14].

Low-dose aspirin leads to peroxidation in human erythrocytes and impairs the antioxidant system [15]. It has been demonstrated that aspirin leads to an increase in the level of MDA, which causes peroxidation in erythrocytes, even at the therapeutic dose [13]. Malondialdehyde is the main product of lipid peroxidation and is one of the indicators of lipid peroxidation that can be measured in vivo [16]. It has been demonstrated that 75 and $100 \mathrm{mg} / \mathrm{kg}$ aspirin administration caused a slight increase in rat liver tissue, but did not decrease the liver antioxidant capacity [13]. It has been revealed that the MDA level in kidney and testicular tissues of rats administered $200 \mathrm{mg} / \mathrm{kg}$ aspirin was significantly higher than the control group [17]). In the present study, ovarian tissue MDA level was determined to be significantly higher in the ASA group than in the control group $(\mathrm{p}<0.05)$. Compared to the group administered only 
paracetamol, rats administered 525 and $50 \mathrm{mg} / \mathrm{kg} \mathrm{CH}$ with paracetamol have been shown to decrease the renal tissue MDA level [18]. In ethanol-induced liver injury, $\mathrm{CH}$ administration has been shown to significantly reduce the levels of the thiobarbituric acid reactive substance, lipid hydroperoxides, and conjugated dienes [19]. In our study, although the ovarian tissue MDA level of the ASA+CH group was lower compared to the ASA group, the difference between the two groups was not significant $(\mathrm{p}>0.05)$. AOPP is a family of protein products containing dityrosine. AOPP is a novel oxidative stress biomarker and proinflammatory mediator and is related to oxidation-related diseases [20]. Excessive reactive oxygen species may induce protein damage, which is an indicator of the increased level of AOPP. Damaged proteins could alter enzyme levels and proteolytic susceptibility, leading to a less active intracellular state, hence contributing to functional and structural impairment of cells [21]. Furthermore, oxidant-mediated protein damage can impair the antioxidant activity of albumin and lead to oxidative burst and synthesis of proinflammatory and inflammatory cytokines, ultimately increasing inflammation and accumulation of oxidants [22]. AOPP can induce the production of reactive oxygen species [20]. AOPP activates the Nf-kB pathway, which plays a crucial role in mediating the suppression of drug-metabolizing enzymes and is produced in numerous pathological processes. $\mathrm{NkB}$ activation is associated with the inflammatory condition, oxidative stress, and activity of drugmetabolizing enzymes as well as with the crosstalk with several nuclear receptors by altering its expression, thereby affecting drug metabolism [23]. It has been revealed that the level of AOPP is elevated in diseases related to oxidative stress such as diabetes [24] and coronary artery patients(213). In the present study, the AOPP level of ovarian tissue was found to be significantly higher in the ASA group compared to the control group $(\mathrm{p}<0.05)$. $\mathrm{CH}$ treatment, on the other hand, significantly decreased the AOPP level caused by aspirin $(\mathrm{p}>0.05)$.

The thiol (-SH) moiety in the side chain of the amino acid of the system is particularly sensitive to redox reactions and is a well-established redox sensor. Protein and many non-protein thiols can form a diverse range of oxidative modifications. Proteins containing reactive thiol groups have the potential to undergo reversible redox regulation and irreversible oxidative modification and inactivation [25]. Plasma thiol groups are physiological free radical scavengers. Protein thiols can preventively scavenge peroxidation-initiating oxidants [26]. Thus, decreased cellular thiol level could be a diagnostic indicator of a pathological condition. Both the reduction in proteolytic degradation and the accumulation of unfolded proteins following severe oxidative stress may be the cause or result of various disorders. Hence, plasma thiols can be considered not only as metabolites or transportable between organs and tissues but also as functionally significant plasma components [27]. In our study, the T-SH level was determined to be significantly lower in the ASA group, compared to the control group $(p<0.05)$. Although the T-SH level of the ASA-CH group was higher than that of the ASA group, this elevation was not significant $(\mathrm{p}>0.05)$.

CAT is an enzymatic antioxidant and a key component of the defense mechanisms of biological systems against ROS activities. CAT is an enzyme that breaks down $\mathrm{H}_{2} \mathrm{O}_{2}$ to $\mathrm{O}_{2}$ and water and is localized in intracellular peroxisomes [18]. It has been demonstrated that ASA leads to a dramatic decrease in CAT activity in rat testis tissue [7]. In our study, although the ovarian tissue CAT activity of the ASA group was lower compared to the control group, this decrease was not significant ( $\mathrm{p}>0.05)$.

It has been shown in numerous studies that $\mathrm{CH}$ treatment protects tissues against oxidative damage and induces an increase in antioxidant enzyme activities [7, 8]. Moreover, it has been found out that $\mathrm{CH}$ could inhibit oxidative stress indirectly by regulating antioxidant enzyme activities [28]. $\mathrm{CH}$ administration has been shown to increase CAT activity in rat liver tissue in the event of liver damage caused by methotrexate [29] and ethanol [19] $\mathrm{CH}$ has a broad range of protective properties against toxicity induced by natural and chemical toxins [30]. In line with the above-mentioned studies, in our study, the ovarian activity of the ASA $+\mathrm{CH}$ group was determined to be significantly higher than the ASA group $(\mathrm{p}<0.05)$.

Long-term use of aspirin might increase oxidative stress in many tissues, albeit it has anti-inflammatory and antioxidant properties. $\mathrm{CH}$ could protect the ovaries from oxidative stress by reducing oxidative stress and increasing the level of antioxidant enzymes. The radical scavenging property of $\mathrm{CH}$ could increase the level of antioxidants by reducing the oxidative stress caused by aspirin.

Conflict of interest: The author declare that they have no conflict of interest. 


\section{References}

1. Aboonabi, A.; Singh, I., The effectiveness of antioxidant therapy in aspirin resistance, diabetes population for prevention of thrombosis. Biomedicine \& Pharmacotherapy 2016, 83, 277-282,

2. Alabi, Q. K.; Adeyemi, W. J., Vernonia amygdalina (Del) as an antioxidant, aspirin toxicity, and oxidative stress. In Toxicology, Elsevier: 2021; pp 491-504.

3. Viuda-Martos, M.; Ruiz-Navajas, Y.; Fernández-López, J.; Pérez-Álvarez, J., Spices as functional foods. Critical reviews in food science and nutrition 2010, 51 (1), 13-28,

4. Zheng, X.; Meng, W.-D.; Xu, Y.-Y.; Cao, J.-G.; Qing, F.-L., Synthesis and anticancer effect of chrysin derivatives. Bioorganic \& Medicinal Chemistry Letters 2003, 13 (5), 881-884,

5. Naz, S.; Imran, M.; Rauf, A.; Orhan, I. E.; Shariati, M. A.; Shahbaz, M.; Qaisrani, T. B.; Shah, Z. A.; Plygun, S.; Heydari, M., Chrysin: Pharmacological and therapeutic properties. Life sciences 2019, 235, 116797,

6. Belhan, S.; Yıldırım, S.; Karasu, A.; Kömüroğlu, A. U.; Özdek, U., Investigation of the protective role of chrysin within the framework of oxidative and inflammatory markers in experimental testicular ischaemia/reperfusion injury in rats. Andrologia 2020, 52 (9), e13714,

7. Dirik, D.; Kömüroğlu, A. U.; Koşal, V.; Başbuğan, Y.; Özdek, U.; Kolusarı, P.; Keleş, Ö. F., Protective Effects of Chrysin in Rats with Ovarian Torsion. Kafkas Univ Vet Fak Derg 2020, 27 (4), 409-415, 10.9775/kvfd.2020.25073.

8. Belhan, S.; Özkaraca, M.; Özdek, U.; Kömüroğlu, A. U., Protective role of chrysin on doxorubicin - induced oxidative stress and DNA damage in rat testes. Andrologia 2020, 52 (9), e13747,

9. Witko-Sarsat, V.; Friedlander, M.; Capeillère-Blandin, C.; Nguyen-Khoa, T.; Nguyen, A. T.; Zingraff, J.; Jungers, P.; Descamps-Latscha, B., Advanced oxidation protein products as a novel marker of oxidative stress in uremia. Kidney international 1996, 49 (5), 1304-1313,

10. Sedlak, J.; Lindsay, R. H., Estimation of total, protein-bound, and nonprotein sulfhydryl groups in tissue with Ellman's reagent. Analytical biochemistry 1968, 25, 192-205,

11. Ohkawa, H., Assay of lipid peroxidation in animal tissues by thiobarbituric acid reaction. Anal Biochem 1979, 95, 371-379,

12. Lartillot, S.; Kedziora, P.; Athias, A., Purification and characterization of a new fungal catalase. Preparative biochemistry 1988, 18 (3), 241-246,

13. Kesik, V.; Lenk, M. K.; Kurekci, A. E.; Acikel, C. H.; Akgul, E. O.; Aydin, A.; Erdem, O.; Gamsizkan, M., Do zinc and selenium prevent the antioxidant, hepatic and renal system impairment caused by aspirin in rats? Biological trace element research 2008, 123 (1), 168-178,

14. Torel, J.; Cillard, J.; Cillard, P., Antioxidant activity of flavonoids and reactivity with peroxy radical. Phytochemistry 1986, 25 (2), 383-385,

15. Durak, I.; Karaayvaz, M.; Cimen, M.; Avci, A.; Çimen, Ö.; Büyukkogak, S.; Oztfirk, H.; Ozbek, H.; Kagmaz, M., Aspirin impairs antioxidant system and causes peroxidation in human erythrocytes and guinea pig myocardial tissue. Human \& experimental toxicology 2001, 20 (1), 34-37,

16. Belhan, S.; Yıldırım, S.; Kayıkçı, C.; Kömüroğlu, A. U.; Özdek, U.; Kuşcu, Y., Investigation of the effect of silymarin on oxidative DNA damageand inflammatory markers in ischemia/reperfusion injuryfollowing experimental testicular torsion/detorsion in rats. Turkish Journal of Zoology 2021, 45 (4), 267-276, 
17. Altintas, R.; Polat, A.; Parlakpinar, H.; Vardi, N.; Beytur, A.; Oguz, F.; Sagir, M.; Yildiz, A.; Duran, Z. R., The effect of melatonin on acetylsalicylic acid-induced kidney and testis damage. Human \& experimental toxicology 2014, 33 (4), 383-395,

18. Kandemir, F. M.; Kucukler, S.; Eldutar, E.; Caglayan, C.; Gülçin, İ., Chrysin protects rat kidney from paracetamol-induced oxidative stress, inflammation, apoptosis, and autophagy: a multi-biomarker approach. Scientia pharmaceutica 2017, 85 (1), 4,

19. Sathiavelu, J.; Senapathy, G. J.; Devaraj, R.; Namasivayam, N., Hepatoprotective effect of chrysin on prooxidant-antioxidant status during ethanol-induced toxicity in female albino rats. Journal of Pharmacy and Pharmacology 2009, 61 (6), 809-817,

20. Xun, T.; Lin, Z.; Wang, X.; Zhan, X.; Feng, H.; Gan, D.; Yang, X., Advanced oxidation protein products downregulate CYP1A2 and CYP3A4 expression and activity via the NF- $\kappa$ Bmediated signaling pathway in vitro and in vivo. Laboratory Investigation 2021, 1-13,

21. Zhou, C.; Zhang, Y.; Chen, J.; Mei, C.; Xiong, F.; Shi, W.; Zhou, W.; Liu, X.; Sun, S.; Tian, J., Association between serum advanced oxidation protein products and mortality risk in maintenance hemodialysis patients. Journal of translational medicine 2021, 19 (1), 1-8,

22. Mera, K.; Anraku, M.; Kitamura, K.; Nakajou, K.; Maruyama, T.; Otagiri, M., The structure and function of oxidized albumin in hemodialysis patients: Its role in elevated oxidative stress via neutrophil burst. Biochem Biophys Res Commun 2005, 334 (4), 1322-8, 10.1016/j.bbrc.2005.07.035.

23. Zordoky, B. N.; El-Kadi, A. O., Role of NF-кB in the regulation of cytochrome P450 enzymes. Current drug metabolism 2009, 10 (2), 164-178,

24. Kalousova, M.; Skrha, J.; Zima, T., Advanced glycation end-products and advanced oxidation protein products in patients with diabetes mellitus. Physiological research 2002, 51 (6), 597604 ,

25. Kayali, R.; Cakatay, U.; Uzun, H.; Genç, H., Gender difference as regards myocardial protein oxidation in aged rats: male rats have increased oxidative protein damage. Biogerontology 2007, $8(6), 653-661$,

26. Kayali, R.; Telci, A.; Cakatay, U.; Karaca, C.; Akcay, T.; Sivas, A.; Altug, T., Oxidative protein damage parameters in plasma in chronic experimental diabetes in rats. European journal of medical research 2003, 8 (7), 307-312,

27. Barsotti, A.; Fabbi, P.; Fedele, M.; Garibaldi, S.; Balbi, M.; Bezante, G. P.; Risso, D.; Indiveri, F.; Ghigliotti, G.; Brunelli, C., Role of advanced oxidation protein products and Thiol ratio in patients with acute coronary syndromes. Clinical biochemistry 2011, 44 (8-9), 605-611,

28. Rehman, M. U.; Tahir, M.; Khan, A. Q.; Khan, R.; Lateef, A.; Oday, O. H.; Qamar, W.; Ali, F.; Sultana, S., Chrysin suppresses renal carcinogenesis via amelioration of hyperproliferation, oxidative stress and inflammation: plausible role of NF-кB. Toxicol Lett 2013, 216 (2-3), 14658, 10.1016/j.toxlet.2012.11.013.

29. Ali, N.; Rashid, S.; Nafees, S.; Hasan, S. K.; Sultana, S., Beneficial effects of Chrysin against Methotrexate-induced hepatotoxicity via attenuation of oxidative stress and apoptosis. Molecular and cellular biochemistry 2014, 385 (1), 215-223,

30. Samarghandian, S.; Farkhondeh, T.; Azimi-Nezhad, M., Protective effects of chrysin against drugs and toxic agents. Dose-Response 2017, 15 (2), 1559325817711782, 